\title{
The relationship between self-efficacy and athlete burnout in elite volleyball players
}

\author{
Koçak Ç.V. ${ }^{\mathrm{ABCDE}}$
}

\author{
Faculty of Sport Sciences, Department of Physical Education and Sport Education, Hitit University, Çorum, Turkey
}

Authors' Contribution: A - Study design; B - Data collection; C - Statistical analysis; D - Manuscript Preparation; E - Funds Collection.

$\begin{array}{ll}\text { Abstract } & \\ \text { Purpose: } & \text { The researches about the relationship between self-efficacy and athlete' burnout of elite volleyball } \\ \text { players who playing in high level leagues is not available in the literature. The aim of this study is to } \\ \text { investigate the relationship between self-efficacy and athletes' burnout in elite volleyball players. } \\ \text { The study group is consisted } 173 \text { [ } n=61 \text { female, } n=112 \text { male] elite volleyball players. The mean of the } \\ \text { age of participants was } 25.6 \text { year [ } \pm 6.3] \text {. Data was collected by personal information form, General Self- } \\ \text { Efficacy Scale [GSE] and Athlete Burnout Questionnaire [ABQ]. SPSS } 22 \text { program was used in the analysis } \\ \text { of the obtained data. Kolmogorov-Smirnov test was applied to determine whether the data showed } \\ \text { normal distribution and the significance level was accepted as } 0.05 \text { in the analyses. Parametric tests were } \\ \text { used in the analysis of the data. } \\ \text { As a result of the research, high level negative correlation was found between effort and resistance sub- } \\ \text { dimension [GSE] and the reduced sense of accomplishment sub-dimension [ABQ] [p<0.01]. In the same } \\ \text { way, there was a negative correlation between ability and confidence sub-dimension [GSE] with reduced } \\ \text { sense of accomplishment sub-dimension [ABQ] [p<0.01]. } \\ \text { This result shows that athletes with high general self-efficacy level have less athlete burnout than others. } \\ \text { Volleyball players who played in national teams have higher self-efficacy than others, while athletes have } \\ \text { less athlete' burnout. Gender has no relation on volleyball players' self-efficacy and burnout. As the age } \\ \text { of the participants decreased, burnout levels increased. } \\ \text { self-efficacy, burnout syndrome, volleyball, player, sport, athletes. }\end{array}$

\section{Introduction}

The level of competition and popularity of sports is increasing rapidly. There are athletes at the center of the growing sport in the sectorial feature and they perform the sport as a profession. Athletes endeavor to achieve lasting success. These efforts include that regular training and competition processes. Intense physical training and stressful competitions are forced to athletes physiologically, mentally and spiritually extreme. Besides, they conduct an intense relationship process with people due to their working environment. This strain and intense relationship process can be a factor in the drift of athletes to burnout.

Self-Efficacy

Self-efficacy is the evaluation of the skills in the context of the content to fullfill a certain task. It is stated the central of the human organism [1]. Self-efficacy is based on personal beliefs about how capable of dealing with the difficulties encountered. It is not a general feeling of self-confidence [2]. Belief of self-efficacy behavior is very important in the acquisition and regulation [3People use their abilities and self-efficacy to change or organize themselves and their environment [4]. On the other hand, self-efficacy belief brings about the expectation of result. The outcome expectations enable the individual to form a cognitive map and methods that may be necessary for the behavior. In this way, he/she determines a tactic and achieves his/her goals. Then he/she directs behavior by loading meaning to the result [5].

\footnotetext{
o Koçak Ç.V., 2019

doi:10.15561/18189172.2019.0504
}

High self-efficacy beliefs contribute to more perseverance, desire, determination and patience [6]. In addition, he/she with high self-efficacy do not hesitate to engage in difficult tasks and activities. On the other hand, he/she with low self-efficacy exhibit an insecure attitude even in the tasks they can actually accomplish and the problems they can overcome. Such people are affected more quickly than stress and depression [6].

\section{Burnout Syndrome}

The concept of burnout was introduced by Freudenberger to literature. Freudenberger [7] has explained the burnout as a state of exhaustion in the individual's internal resources as a result of failure, wear, loss of energy and power, or unmet demands. Also it can be defined is as losing his/her power and not making efforts.

Burnout is not a temporary condition of fatigue or stress caused by excessive stress, such as cooling from his/her job, but rather a permanent condition [8]. Burnout emerges as emotional burnout, devaluation and reduction of personal success [9].

Burnout, which may occur by showing physical, emotional and mental symptoms; can affect the person physically, socially, mentally and spiritually [10]. The factors of affecting the state of burnout are examined in two areas as individual and organizational [environmental] [11]. Differences in environment and personality structures may cause burnout in individuals with different characteristics. One of the person with different personality structure can overcome or may be less affected by the negative consequences. Another 
person may be affected more negatively by the negative conditions that his/her perceives.

\section{Burnout and Sport}

According to Kaçmaz [12], burnout is a factor that directly affects motivation and productivity in the professional life. When the goals are not achieved, the frustration occurs. The physical, mental, emotional and spiritually fatigue and lack of energy can be defined as occupational burnout [13].

According to Eades [14], burnout in sports is psychophysiological syndrome. It emerges in response to chronic stress caused by training and competition of the athlete. It causes that emotional and physical exhaustion, non-human attitude towards other individuals, sense of exclusion by others, decrease in sportive success / performance, loss of meaning of sport for individual, desensitization, role complexity and role ambiguity. It may result leave from the sport.

The potential negative effects of burnout in sports are tried to be measured in a multifaceted manner. The studies that examined the effect of burnout on the level of motivation $[15,16]$, anxiety and self-confidence and stress level are prominent $[17,18]$.

Success and failure are important in the lives of athletes. In other words, athletes express themselves with success. Numerous studies have been conducted in order to examine the performance and self-efficacy relationship in many areas. Self-efficacy researches in sport: The effect of self-efficacy on team success [19], the relationship between superstitious behavior in sports [20] and the selfefficacy level of athletes according to their position are emerging [21].

According to Eades [14], athletes are exposed to excessive physical and psychological stress during long pre-season preparation periods, camps, and competition periods. Athletes may experience emotional and physical exhaustion, which is called burnout in sport, due to the potential failure situations. Also the sense of burnout in elite athletes can lead to a reduction in their academic success. It is important to determine the reasons and the way out of this situation in terms of athlete performance and health.

Behaviors are greatly influenced by self-efficacy belief [22]. Bandura [4] stated that if he/she do not believe that the power to produce solutions to a problem, he/she do not try to solve the problem. From this point of view, it is conceivable that self-efficacy level has positive effect on the elite athletes' coping with burnout syndrome and preventing them from negative effects.

The aim of this study was to investigate the relationship between the levels of self-efficacy and burnout of elite volleyball players who playing elite and to contribute to the literature.

\section{Material and methods}

Model of the Research

Correlational research method was used in the research. In the correlational research, the relationship between two or more variables and the change of variables together are examines. [23]. Relational researches are studies aimed at defining and investigating human behavior in individual and social relations. [24].

Participants:

Participants of the research formed with 173 elite volleyball players who playing volleyball in the 20182019 competition season in Turkey's Super League, 1 st and 2nd league. The volleyball players sampled by convenience sampling method $[25,26]$. Convenience sampling is a method that aims to prevent loss of time, money and labor. Convenience sampling is a frequently used sampling method in the field of sports sciences [24, 27]. The personal information of the volleyball players is presented in Table 1.

Table 1. The personal information of elite volleyball players

\begin{tabular}{|c|c|c|}
\hline Gender & f & $\%$ \\
\hline Female & 61 & 35.3 \\
\hline Male & 112 & 64.7 \\
\hline Total & 173 & 100.0 \\
\hline Age & $f$ & $\%$ \\
\hline $18-22$ & 59 & 34.1 \\
\hline $23-27$ & 58 & 33.5 \\
\hline $28-32$ & 31 & 17,9 \\
\hline $33+$ & 25 & 14.5 \\
\hline Total & 173 & 100.0 \\
\hline Sport experience & $f$ & $\%$ \\
\hline 8-12 year & 72 & 41.6 \\
\hline 13-17 year & 62 & 35.8 \\
\hline 18 year + & 39 & 22.5 \\
\hline Total & 173 & 100.0 \\
\hline Level of league & $\mathrm{f}$ & $\%$ \\
\hline $2^{\text {nd }}$ league & 36 & 20.8 \\
\hline $1^{\text {st }}$ league & 89 & 51.4 \\
\hline Super league & 48 & 27.7 \\
\hline Total & 173 & 100.0 \\
\hline National team career & $f$ & $\%$ \\
\hline Yes & 73 & 42.2 \\
\hline No & 100 & 57.8 \\
\hline Total & 173 & 100.0 \\
\hline Yearly training period & $f$ & $\%$ \\
\hline 8 month & 66 & 38.2 \\
\hline 9 month & 24 & 13.9 \\
\hline 10 month & 52 & 30.1 \\
\hline 11 month & 31 & 17.9 \\
\hline Total & 173 & 100.0 \\
\hline
\end{tabular}

According to Table 1, the research participants consisted of 61 female [35.3\%] and 112 male [64.7\%] elite volleyball players. Age groups of participants were $18-22$ [34.1\%] 23-27 [33.5\%], 28-32 [17.9\%] and 33+ [14.5\%]. The participants are playing in the first league \% 51.4 , in the super league \% 27.7 and in the second league $\%$ 20.8. Looking at the annual training period the rate of 
those who training for 8 months is $38.2 \%$ and the rate of those who train for 10 months is $30.1 \%$.

\section{Procedure:}

"Personal Information Form" which was created by the researcher was used in the determination of the personal information of the athletes. The personal information form includes gender, age, time of sport experience, level of league, national team career and training time throughout the year.

The general self-efficacy levels of the athletes were determined by the General Self-Efficacy Scale [GSE]. The GSE developed by Schwarzer \& Jerusalem [28] and adapted to Turkish by Aypay [29] consists of 10 items and two sub-dimensions. The Cronbach Alpha value for the total of the scale is. 83 .

The burnout levels of the athletes were determined by the Athlete Burnout Questionnaire [ABQ] ABQ developed by Raedeke and Smith [30] and adapted to Turkish by Kelecek et al [31]. consists of 13 items and three subdimensions. The internal consistency coefficient was calculated to range between 0.75 and 0.87 for the scale.

Statistical Analysis:

SPSS 22 program was used in the analysis of the obtained data and Kolmogorov-Smirnov test was applied to determine whether the data showed normal distribution and the significance level was accepted as $p<0.05$ in the analyses. Data were normally distributed. In the analysis of the data, Independent Sample $\mathrm{T}$ Test was applied according to gender and national team career variable. One-Way ANOVA test was applied in the analysis of the variables of the age, sport experience time, league of level, and yearly training period and LSD test was used to determine the significant difference. The Pearson Correlation test was applied to determine the relationship between the general self-efficacy and athlete burnout subdimensions.

\section{Results}

Independent Sample $\mathrm{T}$ Test was used to determine the general self-efficacy and burnout level of participants according to gender.

According to Table 2, it was determined that the differences of general self-efficacy and athlete burnout status were not statistically significant by gender variable $(\mathrm{p}>0.05)$.

One Way ANOVA Test was used to determine the general self-efficacy and burnout level of participants according to age.

In Table 3, the self-efficacy levels in the effort and resistance sub-dimension $\left[\mathrm{F}_{[3.169]=} 7.383 ; \mathrm{p}<0.05 ; \mathrm{p}=.000\right]$ and in the ability and confidence sub-dimension $\left[\mathrm{F}_{[3.169]}=\right.$ 3.944; $\mathrm{p}<0.05 ; \mathrm{p}=.009$ ] it was determined that it had a statistically significant difference by age. In order to determine the difference between the groups, LSD test was applied from post-hoc tests. As a result of LSD test, the difference between the ages of in 18-22 ages and 23$27,28-32$ years and between $23-27,33+$ ages was found to be significant in both dimensions.

The athlete burnout levels in the emotional/physical exhaustion sub-dimension $\left[\mathrm{F}_{[3.169]}=3.119 ; \mathrm{p}<0.05 ; \mathrm{p}=.028\right]$ it was determined that it had a statistically significant difference by age. As a result of LSD test, the difference between the ages of in 18-22, 23-27 ages and 28-32, $33+$ ages was found to be significant. The level of difference in reduced sense of accomplishment and devaluation dimensions was not statistically significant.

One Way ANOVA Test was used to determine the general self-efficacy and burnout level of participants according to sport experience time.

Table 4 shows that the self-efficacy levels in the effort and resistance sub-dimension $\left[\mathrm{F}_{[2.170]}=4.555 ; \mathrm{p}<0.05\right.$; $\mathrm{p}=.012]$ it was determined that it had a statistically significant difference by sport experience time. In order to determine the difference between the groups, LSD test was applied from post-hoc tests. As a result of LSD test, the difference between the 18 year + sport experience time and 8-12, 13-17 years found to be significant.

One Way ANOVA Test was used to determine the general self-efficacy and burnout level of participants according to league of level.

Table 2. Evaluation of general self-efficacy and athlete burnout level by gender.

\begin{tabular}{|c|c|c|c|c|c|c|c|c|}
\hline Scale & Dimensions & Gender & $n$ & $\bar{x}$ & sd & df & $\mathbf{t}$ & $\mathbf{p}$ \\
\hline \multirow{4}{*}{$\begin{array}{l}\text { General Self } \\
\text { Efficacy }\end{array}$} & Effort and & Female & 61 & 3.2459 & .55076 & \multirow{2}{*}{171} & \multirow{2}{*}{-1.539} & \multirow{2}{*}{.126} \\
\hline & Resistance & Male & 112 & 3.3750 & .51382 & & & \\
\hline & \multirow{2}{*}{$\begin{array}{l}\text { Ability and } \\
\text { Confidence }\end{array}$} & Female & 61 & 3.4672 & .47098 & \multirow{2}{*}{171} & \multirow{2}{*}{-.409} & \multirow{2}{*}{.683} \\
\hline & & Male & 112 & 3.4978 & .46920 & & & \\
\hline \multirow{6}{*}{$\begin{array}{l}\text { Athlete } \\
\text { Burnout }\end{array}$} & \multirow{2}{*}{$\begin{array}{l}\text { Emotional/Physical } \\
\text { Exhaustion }\end{array}$} & Female & 61 & 2.3344 & .94989 & \multirow{2}{*}{171} & \multirow{2}{*}{-1.059} & \multirow{2}{*}{.291} \\
\hline & & Male & 112 & 2.4857 & .86856 & & & \\
\hline & \multirow{2}{*}{$\begin{array}{l}\text { Reduced Sense of } \\
\text { Accomplishment }\end{array}$} & Female & 61 & 2.2254 & .87643 & \multirow{2}{*}{171} & \multirow{2}{*}{-.345} & \multirow{2}{*}{.731} \\
\hline & & Male & 112 & 2.2701 & .77919 & & & \\
\hline & \multirow{2}{*}{ Devaluation } & Female & 61 & 1.9139 & .96381 & \multirow{2}{*}{171} & \multirow{2}{*}{-.255} & \multirow{2}{*}{.799} \\
\hline & & Male & 112 & 1.9509 & .88203 & & & \\
\hline
\end{tabular}

Notes: ${ }^{*} p<0.05$ 
Table 3. Evaluation of general self-efficacy and athlete burnout level by age.

\begin{tabular}{|c|c|c|c|c|c|c|c|c|}
\hline Scale & Dimensions & Age & $\mathbf{n}$ & $\bar{x}$ & sd & $\mathbf{F}$ & $\mathbf{p}$ & LSD \\
\hline \multirow{8}{*}{$\begin{array}{l}\text { General Self } \\
\text { Efficacy }\end{array}$} & \multirow{5}{*}{$\begin{array}{l}\text { Effort and } \\
\text { Resistance }\end{array}$} & $18-22$ & 59 & 3.1328 & .56203 & \multirow{4}{*}{7.383} & \multirow{3}{*}{$.000 *$} & \multirow{4}{*}{$\begin{array}{l}1<3<4 \\
2<3<4\end{array}$} \\
\hline & & $23-27$ & 58 & 3.3017 & .51152 & & & \\
\hline & & $28-32$ & 31 & 3.5215 & .47090 & & & \\
\hline & & $33+$ & 25 & 3.6200 & .33513 & & & \\
\hline & & $18-22$ & 59 & 3.3295 & .52917 & \multirow{4}{*}{3.944} & \multirow{4}{*}{$.009 *$} & \multirow{4}{*}{$\begin{array}{l}1<3<4 \\
2<3<4\end{array}$} \\
\hline & \multirow{3}{*}{$\begin{array}{l}\text { Ability and } \\
\text { Confidence }\end{array}$} & $23-27$ & 58 & 3.3729 & .53614 & & & \\
\hline & & $28-32$ & 31 & 3.4483 & .45344 & & & \\
\hline & & $33+$ & 25 & 3.5968 & .39093 & & & \\
\hline \multirow{12}{*}{$\begin{array}{l}\text { Athlete } \\
\text { Burnout }\end{array}$} & \multirow{5}{*}{$\begin{array}{l}\text { Emotional/Physical } \\
\text { Exhaustion }\end{array}$} & $18-22$ & 59 & 3.7100 & .31192 & \multirow{5}{*}{3.119} & \multirow{4}{*}{$.028 *$} & \multirow{4}{*}{$\begin{array}{l}1>2>3>4 \\
4>3\end{array}$} \\
\hline & & $23-27$ & 58 & 3.4870 & .46869 & & & \\
\hline & & $28-32$ & 31 & 2.3695 & .78417 & & & \\
\hline & & $33+$ & 25 & 2.5552 & .96685 & & & \\
\hline & & $18-22$ & 59 & 2.6645 & .83008 & & \multirow{4}{*}{.386} & \\
\hline & \multirow{3}{*}{$\begin{array}{l}\text { Reduced Sense of } \\
\text { Accomplishment }\end{array}$} & $23-27$ & 58 & 2.0080 & .95478 & \multirow{3}{*}{1.018} & & \\
\hline & & $28-32$ & 31 & 2.4324 & .89825 & & & \\
\hline & & $33+$ & 25 & 2.2585 & .84456 & & & \\
\hline & \multirow{4}{*}{ Devaluation } & $18-22$ & 59 & 2.2759 & .80390 & \multirow{4}{*}{.825} & \multirow{4}{*}{.482} & \\
\hline & & $23-27$ & 58 & 2.3952 & .78468 & & & \\
\hline & & $28-32$ & 31 & 2.0200 & .78700 & & & \\
\hline & & $33+$ & 25 & 2.2543 & .81254 & & & \\
\hline
\end{tabular}

Notes: ${ }^{*} p<0.05$

Table 4. Evaluation of general self-efficacy and athlete burnout level by sport experience

\begin{tabular}{|c|c|c|c|c|c|c|c|c|}
\hline Scale & Dimensions & $\begin{array}{l}\text { Sport } \\
\text { Experience }\end{array}$ & $\mathbf{n}$ & $\bar{x}$ & sd & $\mathbf{F}$ & $\mathbf{p}$ & LSD \\
\hline \multirow{6}{*}{$\begin{array}{l}\text { General } \\
\text { Self } \\
\text { Efficacy }\end{array}$} & \multirow{3}{*}{$\begin{array}{l}\text { Effort and } \\
\text { Resistance }\end{array}$} & 8-12 year & 72 & 3.2454 & .52554 & \multirow{3}{*}{4.555} & \multirow{3}{*}{$.012^{*}$} & \multirow{6}{*}{$1<2<3$} \\
\hline & & 13-17 year & 62 & 3.2903 & .54567 & & & \\
\hline & & 18 year + & 39 & 3.5470 & .45715 & & & \\
\hline & \multirow{3}{*}{$\begin{array}{l}\text { Ability and } \\
\text { Confidence }\end{array}$} & 8-12 year & 72 & 3.4375 & .50829 & & & \\
\hline & & 13-17 year & 62 & 3.4758 & .46980 & 1.485 & .229 & \\
\hline & & 18 year + & 39 & 3.5962 & .37441 & & & \\
\hline \multirow{9}{*}{$\begin{array}{l}\text { Athlete } \\
\text { Burnout }\end{array}$} & Emotional/ & 8-12 year & 72 & 2.3139 & .87264 & & & \\
\hline & Physical & 13-17 year & 62 & 2.5677 & .88202 & 1.336 & .266 & \\
\hline & Exhaustion & 18 year + & 39 & 2.4359 & .96122 & & & \\
\hline & \multirow{4}{*}{$\begin{array}{l}\text { Reduced Sense of } \\
\text { Accomplishment }\end{array}$} & 8-12 year & 72 & 2.1632 & .79740 & & & \\
\hline & & 13-17 year & 62 & 2.3629 & .82566 & 1.007 & .367 & \\
\hline & & 18 year + & 39 & 2.2500 & .81918 & & & \\
\hline & & 8-12 year & 72 & 1.7500 & .85168 & & & \\
\hline & \multirow[t]{2}{*}{ Devaluation } & 13-17 year & 62 & 2.0444 & .98921 & 2.762 & .066 & \\
\hline & & 18 year + & 39 & 2.1154 & .83478 & & & \\
\hline
\end{tabular}

Notes: ${ }^{*} p<0.05$

According to Table 5, it was determined that the differences of general self-efficacy and athlete burnout status were not statistically significant by sport experience time variable.

Independent Sample $\mathrm{T}$ Test was used to determine the general self-efficacy and burnout level of participants according to national team career.
Table 6 shows that the self-efficacy levels in the effort and resistance sub-dimension $\left[\mathrm{t}_{[171]}=2.700\right.$; $\mathrm{p}<0.05$; $\mathrm{p}=.005]$ and ability and confidence sub-dimension $\left[\mathrm{t}_{[171]}=\right.$ $2.919 ; \mathrm{p}<0.05 ; \mathrm{p}=.005]$ it was determined that it had a statistically significant difference by national team career variable. In the effort and resistance sub dimension, the averages of the athletes who were previously in the 
national teams were higher $[\bar{x}=3.4543]$ than those who did not $[\bar{x}=3.2383]$. Likewise, in the ability and confidence dimension, the averages of those with a national team career $[\bar{x}=3.6062]$ is higher than those without $[\bar{x}=3.4000]$.

There is a statistically significant difference in reduced sense of accomplishment dimension $\left[\mathrm{t}_{[171]}=-2.167 ; \mathrm{p}<0.05\right.$; $\mathrm{p}=.005]$ according to career variable of burnout levels. In the reduced sense of accomplishment sub dimension the averages of the athletes who were previously in the national teams were higher $[\bar{x}=.81195]$ than those who $\operatorname{did} \operatorname{not}[\bar{x}=.79808]$.

One Way ANOVA Test was used to determine the general self-efficacy and burnout level of participants according to yearly training period.

Table 7 shows that the self-efficacy levels in the effort and resistance sub-dimension $\left[\mathrm{F}_{[3.169]}=3.112 ; \mathrm{p}<0.05\right.$; $\mathrm{p}=.028$ ] it was determined that it had a statistically significant difference by yearly training period. In order to determine the difference between the groups, LSD test was applied from post-hoc tests. As a result of LSD test, the difference between the 9 month training period and 8 month, 10 month and 11 month training periods found to be significant.

Pearson Correlation test was used to evaluate the relationship between general self-efficacy and athletic burnout sub-dimensions.

According to Table 8, a negative correlation was found between sub-dimensions of self-efficacy, effort and resistance and the sub-dimensions of athlete burnout scale; reduced sense of accomplishment [ $\mathrm{r}=-.225$, $\mathrm{p}=.003]$. In the same way, there was a negative correlation between ability and confidence sub-dimension with subdimensions of athlete burnout scale, reduced sense of accomplishment $[r=-.265, \mathrm{p}=.000]$.

Table 5. Evaluation of general self-efficacy and athlete burnout level by league of level

\begin{tabular}{|c|c|c|c|c|c|c|c|}
\hline Scale & Dimensions & League of Level & $\mathbf{n}$ & $\bar{x}$ & sd & $\mathbf{F}$ & $\mathbf{p}$ \\
\hline \multirow{6}{*}{$\begin{array}{l}\text { General } \\
\text { Self } \\
\text { Efficacy }\end{array}$} & \multirow{3}{*}{$\begin{array}{l}\text { Effort and } \\
\text { Resistance }\end{array}$} & $2^{\text {nd }}$ league & 36 & 3.3380 & .53967 & \multirow{3}{*}{1.020} & \multirow{3}{*}{.363} \\
\hline & & $1^{\text {st }}$ league & 89 & 3.3745 & .47625 & & \\
\hline & & Super league & 48 & 3.2396 & .60914 & & \\
\hline & \multirow{3}{*}{$\begin{array}{l}\text { Ability and } \\
\text { Confidence }\end{array}$} & $2^{\text {nd }}$ league & 36 & 3.4167 & .42258 & \multirow{3}{*}{.528} & \multirow{3}{*}{.591} \\
\hline & & $1^{\text {st }}$ league & 89 & 3.5112 & .44420 & & \\
\hline & & Super league & 48 & 3.4948 & .54453 & & \\
\hline \multirow{9}{*}{$\begin{array}{l}\text { Athlete } \\
\text { Burnout }\end{array}$} & \multirow{3}{*}{$\begin{array}{l}\text { Emotional/Physical } \\
\text { Exhaustion }\end{array}$} & $2^{\text {nd }}$ league & 36 & 2.1722 & 1.02221 & \multirow{3}{*}{2.632} & \multirow{3}{*}{.075} \\
\hline & & $1^{\text {st }}$ league & 89 & 2.5663 & .84919 & & \\
\hline & & Super league & 48 & 2.3792 & .85775 & & \\
\hline & \multirow{3}{*}{$\begin{array}{l}\text { Reduced Sense of } \\
\text { Accomplishment }\end{array}$} & $2^{\text {nd }}$ league & 36 & 2.1597 & .83699 & \multirow{3}{*}{.629} & \multirow{3}{*}{.534} \\
\hline & & $1^{\text {st }}$ league & 89 & 2.3202 & .81271 & & \\
\hline & & Super league & 48 & 2.2031 & .80003 & & \\
\hline & \multirow{3}{*}{ Devaluation } & $2^{\text {nd }}$ league & 36 & 1.7083 & .95525 & \multirow{3}{*}{2.326} & \\
\hline & & $1^{\text {st }}$ league & 89 & 1.9242 & .92427 & & \multirow{2}{*}{.101} \\
\hline & & Super league & 48 & 2.1354 & .81534 & & \\
\hline
\end{tabular}

Notes: ${ }^{*} p<0.0$

Table 6. Evaluation of general self-efficacy and athlete burnout level by national team career

\begin{tabular}{|c|c|c|c|c|c|c|c|c|}
\hline Scale & Dimensions & $\begin{array}{l}\text { National } \\
\text { Team } \\
\text { Career }\end{array}$ & $\mathbf{n}$ & $\bar{x}$ & sd. & df & $\mathbf{t}$ & $\mathbf{p}$ \\
\hline \multirow{4}{*}{$\begin{array}{l}\text { General } \\
\text { Self } \\
\text { Efficacy }\end{array}$} & Effort and & Yes & 73 & 3.4543 & .49086 & \multirow{2}{*}{171} & \multirow{2}{*}{2.700} & \multirow{2}{*}{$.008^{*}$} \\
\hline & Resistance & No & 100 & 3.2383 & .53980 & & & \\
\hline & Ability and & Yes & 73 & 3.6062 & .46755 & \multirow{2}{*}{171} & \multirow{2}{*}{2.919} & \multirow{2}{*}{$.004^{*}$} \\
\hline & Confidence & No & 100 & 3.4000 & .45227 & & & \\
\hline \multirow{6}{*}{$\begin{array}{l}\text { Athlete } \\
\text { Burnout }\end{array}$} & Emotional/Physical & Yes & 73 & 2.5205 & .90966 & \multirow{2}{*}{171} & \multirow{2}{*}{1.104} & \multirow{2}{*}{.271} \\
\hline & Exhaustion & No & 100 & 2.3680 & .88886 & & & \\
\hline & \multirow{2}{*}{$\begin{array}{l}\text { Reduced Sense of } \\
\text { Accomplishment }\end{array}$} & Yes & 73 & 2.0993 & .81195 & \multirow{2}{*}{171} & \multirow{2}{*}{-2.167} & \multirow{2}{*}{$.032 *$} \\
\hline & & No & 100 & 2.3675 & .79808 & & & \\
\hline & \multirow{2}{*}{ Devaluation } & Yes & 73 & 1.9418 & .86955 & \multirow{2}{*}{171} & \multirow{2}{*}{.048} & \multirow{2}{*}{.962} \\
\hline & & No & 100 & 1.9350 & .94121 & & & \\
\hline
\end{tabular}

Notes: ${ }^{*} \mathrm{p}<0.05$ 
Table 7. Evaluation of general self-efficacy and athlete burnout level by yearly training period

\begin{tabular}{|c|c|c|c|c|c|c|c|c|}
\hline Scale & Dimensions & $\begin{array}{l}\text { Yearly Training } \\
\text { Period }\end{array}$ & $\mathbf{n}$ & $\bar{x}$ & sd & $\mathbf{F}$ & $\mathbf{p}$ & LSD \\
\hline \multirow{8}{*}{$\begin{array}{l}\text { General } \\
\text { Self } \\
\text { Efficacy }\end{array}$} & & 8 month & 66 & 3.3333 & .53669 & \multirow{5}{*}{3.112} & \multirow{5}{*}{$.028^{*}$} & \multirow{8}{*}{$2<1-3-4$} \\
\hline & Effort and & 9 month & 24 & 3.0486 & .69761 & & & \\
\hline & Resistance & 10 month & 52 & 3.3782 & .43048 & & & \\
\hline & \multirow{5}{*}{$\begin{array}{l}\text { Ability and } \\
\text { Confidence }\end{array}$} & 11 month & 31 & 3.4570 & .45738 & & & \\
\hline & & 8 month & 66 & 3.4924 & .44065 & & & \\
\hline & & 9 month & 24 & 3.3021 & .64260 & \multirow{3}{*}{2.248} & \multirow{3}{*}{.085} & \\
\hline & & 10 month & 52 & 3.4808 & .45870 & & & \\
\hline & & 11 month & 31 & 3.6290 & .34078 & & & \\
\hline \multirow{12}{*}{$\begin{array}{l}\text { Athlete } \\
\text { Burnout }\end{array}$} & \multirow{5}{*}{$\begin{array}{l}\text { Emotional/ } \\
\text { Physical } \\
\text { Exhaustion }\end{array}$} & 8 month & 66 & 2.5061 & .84651 & \multirow{4}{*}{1.279} & \multirow{4}{*}{.283} & \\
\hline & & 9 month & 24 & 2.3083 & .80645 & & & \\
\hline & & 10 month & 52 & 2.5385 & .92845 & & & \\
\hline & & 11 month & 31 & 2.1935 & 1.00331 & & & \\
\hline & & 8 month & 66 & 2.2992 & .87620 & \multirow{4}{*}{2.004} & \multirow{4}{*}{.115} & \\
\hline & \multirow{3}{*}{$\begin{array}{l}\text { Reduced Sense of } \\
\text { Accomplishment }\end{array}$} & 9 month & 24 & 1.9063 & .71783 & & & \\
\hline & & 10 month & 52 & 2.3798 & .82470 & & & \\
\hline & & 11 month & 31 & 2.2177 & .66377 & & & \\
\hline & \multirow{4}{*}{ Devaluation } & 8 month & 66 & 1.9470 & .98500 & \multirow{4}{*}{1.020} & \multirow{4}{*}{.385} & \\
\hline & & 9 month & 24 & 1.6875 & .64374 & & & \\
\hline & & 10 month & 52 & 2.0721 & .91600 & & & \\
\hline & & 11 month & 31 & 1.8871 & .89870 & & & \\
\hline
\end{tabular}

Notes: ${ }^{*} p<0.05$

Table 8. Evaluation of the relationship between general self-efficacy and sub-dimensions of athlete burnout

\begin{tabular}{lllll}
\hline Scales & & $\begin{array}{l}\text { Emotional/ } \\
\text { Physical Exhaustion }\end{array}$ & $\begin{array}{l}\text { Reduced } \\
\text { Sense of Accomplishment }\end{array}$ & Devaluation \\
\hline \multirow{2}{*}{ Effort and Resistance } & $r$ & -.029 & $-.225^{* *}$ & -.094 \\
& $\mathrm{p}$ & .708 & .003 & .220 \\
\hline \multirow{2}{*}{ Ability and Confidence } & $\mathrm{r}$ & -.023 & $-.265^{* *}$ & -.097 \\
& $\mathrm{p}$ & .762 & .000 & .206 \\
\hline
\end{tabular}

Notes: $* * p<0.01$

\section{Discussion}

In this study, the relationship between general selfefficacy and athlete burnout levels among elite volleyball players were examined in Turkey. There was no significant difference between the male and female athletes in the sub-dimensions of general self-efficacy and athletes' burnout. There are studies in literature suggesting that athlete' performance may be optimal when burnout is minimal [32-34].

It was seen that the self-efficacy and burnout levels of the participants were statistically significant according to the age variable. It is seen that as the age increases, the level of general self-efficacy increases. It is observed that the level of burnout increases at an early age in the emotional/physical exhaustion dimension. This situation can be interpreted as the age factor in sports, with experience and maturation, and the fact that older athletes are able to better manage the physiological/psychological forcing and the stress experienced and they are less affected.
It has been determined that the experience of the athletes have a positive effect on the level of general self-efficacy. As the experience of athletes increases, selfefficacy level increases. The time spent in sports training brings along the development of skills. The improvement of experiences and skills can affect the level of selfconfidence positively. There are studies [35-37] that indicate the effect of self-efficacy of sports experience in the literature.

There was no significant relationship between volleyball players' league of level and self-efficacy and burnout levels in this study. This situation can be interpreted as the high degree of difficulty of the league at each level.

It was determined that the self-efficacy levels of the participants who took part as athletes in national teams were higher than those who did not. A negative relationship was found between the national team career and burnout level. The burnout levels of the athletes with a national team career are lower than the other athletes in 
the dimension of reduced sense of accomplishment. It is likely that the knowledge, skills and experiences acquired in the elite level, such as national teams, will positively affect self-efficacy. This result can be interpreted that high-level athletes internalize their achievements and experience a decreasing sense of success less than other athletes.

It can be thought that doing training in the majority of the year and it will bring about athletes' burnout. However, in this study, the effect of annual training period on burnout has not been reached. On the other hand, the relationship between training period and effort and resistance self-efficacy were determined. Athletes who have trained for 9 months show higher effort and resistance self-efficacy than who work in 8, 10, and 11 months during year. This result shows that a 9-month training period may be more appropriate for athletes who spend most of the year training.

\section{Conclusion}

The primary purpose of this study was to examine the relationship between general self-efficacy and athlete's burnout. According to correlation analyses a negative correlation was found between effort and resistance sub-dimension and reduced sense of accomplishment sub-dimension. In the same way there was a negative correlation between ability and confidence sub-dimension with reduced sense of accomplishment sub-dimension. This result shows that athletes with high general selfefficacy level have less reduced sense of accomplishment than others. The lack of detailed studies on general selfefficacy and athletes' burnout relation in the literature makes it difficult to compare the results of the study with the literature.

Based on the results obtained, it may be suggested that athletes develop their self-efficacy in order not to be adversely affected by burnout. The relationship between general self-efficacy and athlete's burnout should be investigated in different samples with different variables.

\section{Conflict of interest}

There were no conflicts of interest.

\section{References}

1. Pajares F. Current directions in self-efficacy research. Advances in motivation and achievement. 1997; 10 (149):149.

2. Bartel AP, Lichtenberg FR. The Comparative Advantage of Educated Workers in Implementing New Technology. The Review of Economics and Statistics, 1987;69:1. https://doi.org/10.2307/1937894

3. Bandura A. Social Cognitive Theory: An Agentic Perspective. Annual Review of Psychology, 2001;52:1-26. https://doi.org/10.1146/annurev.psych.52.1.1

4. Bandura A. Self efficacy: The exercise of control. New York: W. H. Freeman; 1997.

5. Schunk DH, Pajares F. Self-efficacy theory. Handbook of motivation at school (e-book); 2009.

6. Pajares F. Self-efficacy beliefs in academic settings. Review of educational research. 1996. 66 (4), 543-578. https://doi.org/10.3102/00346543066004543

7. Freudenberger HJ. Staff burn-out. Journal of social issues. $1974.30 \quad$ (1), 159-165. https://doi.org/10.1111/j.1540-4560.1974.tb00706.x

8. Avşaroğlu S, Deniz ME, Kahraman A. Examination of life satisfaction job satisfaction and occupational burnout levels in technical teachers. Selcuk University Journal of Social Sciences Institute. 2005; (14): 115-129.

9. Maslach C, Schaufeli WB, Leiter MP. Job burnout. Annual review of psychology. 2001;52 (1):397-422. https://doi.org/10.1146/annurev.psych.52.1.397

10.Ersoy F, Yıldırım C, Edirne T. Staff burnout syndrome. Journal Of Continuing Medical Education. 2001;10 (2):1-10.

11. Sürgevil O. Burnout syndrome in work life: Burnout techniques. Ankara: Nobel Yayın; 2006. (In Turkish)

12.Kaçmaz N. Burnout syndrome. Journal of Istanbul Faculty of Medicine. 2005;68 (1).29-32.

13.Maslach C, Zimbardo PG. Burnout- The Cost of Caring. New Jersey: Prentice-Hall, Inc., Englewood Cliffs; 1982.

14.Eades AM. An investigation of burnout of intercollegiate athletes: The development of the Eades Athlete Burnout Inventory. Berkeley: University of California; 1990.
15.Gustafsson H, Hassmén P, Kenttä G, Johansson M. A qualitative analysis of burnout in elite Swedish athletes. Psychology of Sport and Exercise, 2008;9:800-16. https://doi.org/10.1016/j.psychsport.2007.11.004

16.Lemyre PN, Roberts GC, Stray-Gundersen J. Motivation, overtraining, and burnout: Can self determination predict overtraining and burnout in elite athletes?. European Journal of Sport Science. 2007; 7: 115-126. https://doi.org/10.1080/17461390701302607

17.Londsdale C, Hodge K, Rose E. Athlete burnout in elite sport: A self-determination perspective. Journal of Sport Sciences. 2009; 27 (8): 785-795. https://doi.org/10.1080/02640410902929366

18.Cremades JG, Wated G, Wiggins, MS. Multiplicative measurements of a trait anxiety scale as predictors of burnout. Measurement in Physical Education and Exercise Science. 2011; 15 (3): 220-233. https://doi.org/10.1080/1091367X.2011.594356

19.Öcal H, Aydin O. The Relationships of Collective Efficacy Beliefs, Self Efficacy Beliefs and Group Cohesiveness with Success Evaluations and Expectancies in Sports Teams. Journal of Faculty of Letters. 2009;26 (2): 155-174.

20.Barut Aİ. Relation of superstitious behavior in sport and selfefficacy [Thesis]. Mersin: Mersin University, Turkey; 2008.

21.Žakula G, Tubić T, Jovanović S. Generalized selfefficacy of handball players according to playing position in the team. SportLogia. 2017; 13 (1): 46-52. https://doi.org/10.5550/sgia.171301.en.ZTJ

22.Bandura A. Social cognitive theory of personality. Handbook of personality. 1999; 2: 154-196.

23.Fraenkel JR, Wallen NE. How to design and evaluate research in education. Mc Grawall Hill; 2006.

24.Cohen LM, Manion LL. Research Methods in Education. New York: Routledge; 1998.

25.Büyüköztürk Ş, Çakmak EK., Akgün ÖE., Karadeniz Ş, Demirel F. Scientific research methods. Pegem Atuf Indeksi. 2017;1: 1-360. https://doi.org/10.14527/9789944919289

26.Koçak F. The relationship between leisure constraints, 
constraint negotiation strategies and facilitators with recreational sport activity participation of college students. College Student Journal. 2017; 51 (4): 491-497.

27.Koçak F. Leisure constraints and faciltators: Perspectives from Turkey. European Journal of Physical Education and Sport Science. 2017; 3 (10): 32-47. http://dx.doi.org/10.5281/zenodo.852540

28.Schwarzer R, Jerusalem M. Generalized self-efficacy scale. In: Weinman J, Wright S, Johnston M. (Eds.), Measures in health psychology: A user's portfolio. Causal and control beliefs, Windsor, UK: NFER-Nelson; 1995. P. 35-37.

29.Aypay A. The Adaptation Study of General Self-Efficacy (GSE) Scale to Turkish. Inonu University Journal of The Faculty of Education. 2010; 11 (2): 113-131.

30.Raedeke TD, Smith AL. Development and preliminary validation of an athlete burnout measure. Journal of Sport And Exercise Psychology. 2001; 23 (4): 281-306. https://doi.org/10.1123/jsep.23.4.281

31.Kelecek S, Kara FM, Kazak Çetinkalp Z, Aşçı FH. The Turkish Adaptation Of "Athlete Burnout Questionnaire". Hacettepe Journal of Sport Sciences. 2016; 27 (4):149-161. https://doi.org/10.17644/sbd.311371

32.Madigan DJ, Nicholls AR. Mental toughness and burnout in junior athletes: A longitudinal investigation. Psychology of Sport and Exercise. 2017; 32: 138-142. https://doi.org/10.1016/j.psychsport.2017.07.002
33.Gucciardi DF, Gordon S, Dimmock JA. Advancing mental toughness research and theory using personal construct psychology. International Review of Sport and Exercise Psychology. 2009; 2 (1): 54-72. https://doi.org/10.1080/17509840802705938

34.Martin EM, Horn TS. The role of athletic identity and passion in predicting burnout in adolescent female athletes. The Sport Psychologist. 2013; 27 (4): 338-348. https://doi.org/10.1123/tsp.27.4.338

35.Jagiello M, Iermakov SS, Nowinski M. Differentiation of the somatic composition of students physical education specialising in various sports. Archives of Budo Science of Martial Arts and Extreme Sports. 2017;13:63-70.

36.Podrigalo L, Iermakov S, Romanenko V, Rovnaya O, Tropin Y, Goloha V, et al. Psychophysiological features of athletes practicing different styles of martial arts - the comparative analysis. International Journal of Applied Exercise Physiology. 2019;8(1):84-91. https://doi.org/10.30472/ijaep.v8i1.299

37.Feltz DL, Hepler TJ, Roman N, Paiement C. Coaching efficacy and volunteer youth sport coaches. The sport psychologist. 2009; 23 (1): 24-41. https://doi.org/10.1123/tsp.23.1.24

\section{Information about the author:}

Koçak Ç.V.; http://orcid.org/0000-0002-1403-0812; velikocak@hitit.edu.tr; Faculty of Sport Sciences, Department of Physical Education and Sport Education, Hitit University; North Campus, Ring Road, 19030, Corum, Turkey.

Cite this article as:

Koçak ÇV. The relationship between self-efficacy and athlete burnout in elite volleyball players. Pedagogics, psychology, medical-biological problems of physical training and sports, 2019;23(5):231-238. https://doi.org/10.15561/18189172.2019.0504

This is an Open Access article distributed under the terms of the Creative Commons Attribution License, which permits unrestricted use, distribution, and reproduction in any medium, provided the original work is properly cited (http://creativecommons.org/licenses/by/4.0/deed.en).

Received: 30.05.2019

Accepted: 30.06.2019; Published: 17.09.2019 